\title{
Effects of Intercropping with Accumulator on Nutrient Uptake of Galinsoga parviflora under Cd-Contaminated Soil
}

\author{
Jin Wang ${ }^{1, a}$, Shuting Yang ${ }^{1, b}$, Jun Shi ${ }^{2, c}$ and Xiulan $L v^{3, d *}$ \\ ${ }^{1}$ College of Horticulture, Sichuan Agricultural University, Chengdu, Sichuan, China \\ ${ }^{2}$ Mianyang Academy of Agricultural Sciences, Mianyang, Sichuan, China \\ ${ }^{3}$ Institute of Pomology and Olericulture, Sichuan Agricultural University, Chengdu, Sichuan, China

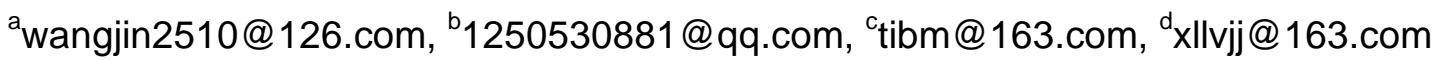 \\ ${ }^{*}$ Corresponding author
}

\begin{abstract}
Keywords: Intercropping; Accumulator; Cadmium contamination; Galinsoga parviflora; Nutrient uptake
\end{abstract}

Abstract. The effects of intercropping with accumulator species (Capsella bursa-pastoris, Cardamine hirsute and Galium aparine) on phosphorus (P) and potassium (K) uptakes of Galinsoga parviflora under cadmium $(\mathrm{Cd})$ contaminated soil were studied through the pot experiment. Seven treatments were used in the experiment: monoculture of $G$. parviflora, monoculture of $C$. bursa-pastoris, monoculture of $C$. hirsute, monoculture of $G$. aparine, G. parviflora intercropping C. bursa-pastoris, $G$. parviflora intercropping $C$. hirsute and $G$. parviflora intercropping $G$. aparine. When intercropping with three accumulator species, the total $\mathrm{P}$ and $\mathrm{K}$ contents in roots and shoots of $G$. parviflora were ranked as: G. parviflora (intercropping with $G$. aparine) > G. parviflora (monoculture) $>G$. parviflora (intercropping with $C$. hirsute) $>G$. parviflora (intercropping with $C$. bursa-pastoris). When intercropping with $G$. parviflora, the total $\mathrm{P}$ and $\mathrm{K}$ contents in roots and shoots of $C$. bursa-pastoris increased, but the total $\mathrm{P}$ and $\mathrm{K}$ contents in roots and shoots of $C$. hirsute and $G$. aparine decreased compared with monoculture respectively. Therefore, intercropping with $G$. aparine could used to increase nutrient uptake of $G$. parviflora in Cd-contaminated soil.

\section{Introduction}

Intercropping is used to improve the yield and quality in agricultural production [1]. Under heavy metal stress, intercropping increase heavy metal uptake in hyperaccumulator, and decrease heavy metal uptake in common plant [2]. But other study shows no effect of heavy metal uptake in two plant spaces [3]. These results indicate that only suitable plant species intercropping could affect heavy metal uptake. Galinsoga parviflora is a cadmium (Cd) hyperaccumulator with small biomass [4]. In this experiment, we intercropped $G$. parviflora with three Cd-accumulator species Capsella bursa-pastoris [5], Cardamine hirsute [6] and Galium aparine (screened in early experiment). The aim of the study was to determine if intercropping with accumulator species could efficiently promote the nutrient uptake of $G$. parviflora, and improve the phytoremediation ability of G. parviflora.

\section{Materials and Methods}

Materials. G. parviflora, C. bursa-pastoris, C. hirsute and G. aparine seedlings with two euphyllas were collected from Ya'an campus farm of Sichuan Agricultural University $\left(29^{\circ} 59^{\prime} \mathrm{N}, 102^{\circ} 59^{\prime} \mathrm{E}\right)$, China, in September 2013. The purple soil samples came from Cd-contaminated soil in the earlier experiment of Ya'an campus Farm. The basic properties of the soil were the same as reference [4].

Experimental Design. The experiment was conducted at the Ya'an campus farm from September to October in 2013. The soil samples were air-dried and passed through a 5-mm sieve. Three kilograms of the air-dried soil was weighed into each polyethylene pot (15 cm high, $18 \mathrm{~cm}$ in diameter). The seven experimental treatments in the experiment were monoculture of $G$. parviflora, monoculture of $C$. bursa-pastoris, monoculture of $C$. hirsute, monoculture of $G$. aparine, G. parviflora intercropping $C$. 
bursa-pastoris, G. parviflora intercropping C. hirsute and G. parviflora intercropping G. aparine. The seedlings of monoculture were 4 , and the seedlings of intercropping were 2 of each plant species. Each treatment was replicated three times using a completely randomized design with $10-\mathrm{cm}$ spacing between pots. Four uniform seedlings of $G$. parviflora were transplanted into each pot and the soil moisture content was maintained at $80 \%$ of field capacity from the time the plants were transplanted into the pots until the time the plants were harvested. At maturity (after $35 \mathrm{~d}$ ), the entire plants were harvested for determining contents of total $\mathrm{P}$ and $\mathrm{K}$ in roots and shoots [7]. The soil samples were collected for determining soil available $\mathrm{P}$ and $\mathrm{K}$ contents [7] and soil enzyme activity [8].

\section{Results and Discussion}

Effects of intercropping on total $\mathbf{P}$ content in four plant species. When intercropping with $C$. bursa-pastoris, $C$. hirsute and G. aparine under Cd-contaminated soil, the total P contents in roots and shoots of G. parviflora were ranked as: G. parviflora (intercropping with G. aparine) $>$ G. parviflora (monoculture) $>G$. parviflora (intercropping with $C$. hirsute) $>G$. parviflora (intercropping with $C$. bursa-pastoris) (Fig. 1). Compared with monoculture, intercropping with $C$. bursa-pastoris and $C$. hirsute decreased the total P content in roots of G. parviflora by $4.19 \%(p>0.05)$ and $1.82 \%(p>0.05)$ respectively, decreased by $13.44 \%(p<0.05)$ and $6.98 \%(p>0.05)$ in shoots of G. parviflora respectively. Intercropping with $G$. aparine increased the total P contents in roots and shoots of $G$. parviflora by $1.19 \%(p>0.05)$ and $21.58 \%(p<0.05)$ compared with monoculture respectively. When intercropping with $G$. parviflora, the total $\mathrm{P}$ contents in roots and shoots of $C$. bursa-pastoris increased, but the total $\mathrm{P}$ contents in roots and shoots of $C$. hirsute and $G$. aparine decreased compared with monoculture respectively. Compared with respective monoculture, intercropping with G. parviflora increased total P contents in roots and shoots of $C$. bursa-pastoris by $29.56 \%(p<0.05)$ and $10.69 \%(p<0.05)$ respectively, decreased total $\mathrm{P}$ contents in roots and shoots of $C$. hirsute by $38.39 \%(p<0.05)$ and $29.63 \%(p<0.05)$ respectively, and decreased total $\mathrm{P}$ contents in roots and shoots of $C$. hirsute by $26.83 \%(p<0.05)$ and $14.76 \%(p<0.05)$ respectively.

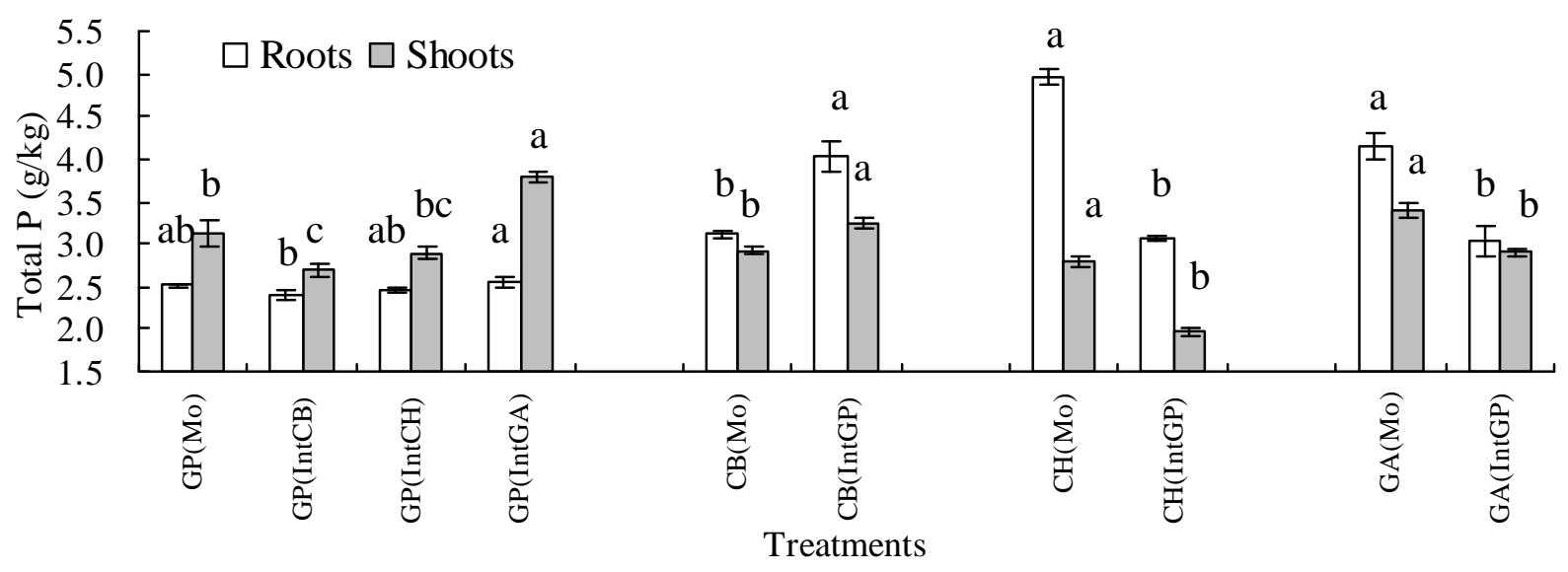

Fig. 1 Effects of intercropping on total P content in four plant species. Values are means of three replicate pots. Different lowercase letters indicate significant differences based on one-way analysis of variance in SPSS 13.0 followed by the least significant difference test $(p<0.05)$. $\mathrm{GP}(\mathrm{Mo})=$ monoculture of G. parviflora, $\mathrm{CB}(\mathrm{Mo})=$ monoculture of $C$. bursa-pastoris, $\mathrm{CH}(\mathrm{Mo})=$ monoculture of $C$. hirsute, $\mathrm{GA}(\mathrm{Mo})=$ monoculture of $G$. aparine, GPIntCB $=G$. parviflora intercropping with $C$. bursa-pastoris, GPIntCH $=G$. parviflora intercropping with $C$. hirsute, $\mathrm{GPIntGA}=$ G. parviflora intercropping with G. aparine.

Effects of intercropping on total $\mathbf{K}$ content in four plant species. The same as total $\mathrm{P}$ content in $G$. parviflora, when intercropping with $C$. bursa-pastoris, $C$. hirsute and $G$. aparine in Cd-contaminated soil, the total K contents in roots and shoots of $G$. parviflora were ranked as: $G$. parviflora (intercropping with $G$. aparine) > G. parviflora (monoculture) > G. parviflora (intercropping with $C$. hirsute) $>$ G. parviflora (intercropping with C. bursa-pastoris) (Fig. 2). Compared with monoculture, intercropping with $C$. bursa-pastoris and $C$. hirsute decreased the total 
K content in roots of $G$. parviflora by $8.36 \%(p<0.05)$ and $6.47 \%(p>0.05)$ respectively, decreased by $14.08 \%(p<0.05)$ and $5.60 \%(p<0.05)$ in shoots of $G$. parviflora respectively. Intercropping with G. aparine increased the total K contents in roots and shoots of G. parviflora by $21.29 \%(p<0.05)$ and $4.16 \%(p>0.05)$ compared with monoculture respectively. When intercropping with $G$. parviflora, the total $\mathrm{K}$ contents in roots and shoots of $C$. bursa-pastoris increased, but the total $\mathrm{K}$ contents in roots and shoots of $C$. hirsute and $G$. aparine decreased compared with respective monoculture. Compared with respective monoculture, intercropping with G. parviflora increased total $\mathrm{K}$ contents in roots and shoots of $C$. bursa-pastoris by $2.97 \%(p>0.05)$ and $1.77 \%(p>0.05)$ respectively, decreased total $\mathrm{K}$ contents in roots and shoots of $C$. hirsute by $14.60 \%(p>0.05)$ and $12.35 \%(p>0.05)$ respectively, and decreased total $\mathrm{K}$ contents in roots and shoots of $C$. hirsute by $4.22 \%(p>0.05)$ and $1.83 \%(p>0.05)$ respectively.

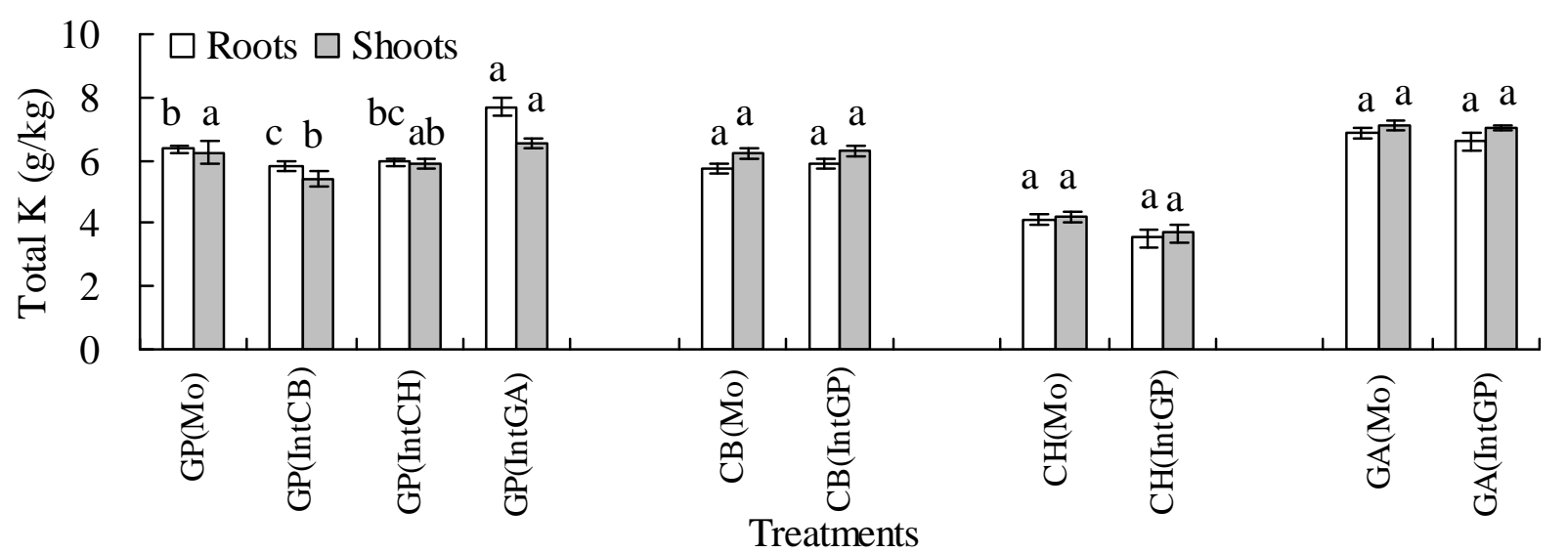

Fig. 1 Effects of intercropping on total $\mathrm{K}$ content in four plant species. Values are means of three replicate pots. Different lowercase letters indicate significant differences based on one-way analysis of variance in SPSS 13.0 followed by the least significant difference test $(p<0.05)$. $\mathrm{GP}(\mathrm{Mo})=$ monoculture of $G$. parviflora, $\mathrm{CB}(\mathrm{Mo})=$ monoculture of $C$. bursa-pastoris, $\mathrm{CH}(\mathrm{Mo})=$ monoculture of $C$. hirsute, $\mathrm{GA}(\mathrm{Mo})=$ monoculture of $G$. aparine, $\mathrm{GPIntCB}=G$. parviflora intercropping with $C$. bursa-pastoris, GPIntCH $=G$. parviflora intercropping with $C$. hirsute, $\mathrm{GPIntGA}=$ G. parviflora intercropping with $G$. aparine.

Soil available $\mathbf{P}$ content. When $G$. parviflora intercropped with $C$. bursa-pastoris, the soil available $\mathrm{P}$ content was higher than that of both $G$. parviflora (monoculture) and $C$. bursa-pastoris (monoculture) (Table 1). The soil available P content of $G$. parviflora intercropping with $C$. hirsute was lower than that of G. parviflora (monoculture), and higher than that of $C$. hirsute (monoculture) respectively. The soil available P content of $G$. parviflora intercropping with $G$. aparine was higher than that of both G. parviflora (monoculture) and G. aparine (monoculture).

Soil available $\mathrm{K}$ content. When $G$. parviflora intercropped with $C$. bursa-pastoris, the soil available $\mathrm{K}$ content was lower than that of both $G$. parviflora (monoculture) and $C$. bursa-pastoris (monoculture) (Table 1). The soil available K content of $G$. parviflora intercropping with $C$. hirsute was lower than that of G. parviflora (monoculture), and higher than that of $C$. hirsute (monoculture) respectively. The soil available K content of $G$. parviflora intercropping with $G$. aparine was higher than that of both G. parviflora (monoculture) and G. aparine (monoculture).

Soil enzyme activity. The soil sucrase activities of $G$. parviflora intercropping with $C$. bursa-pastoris and $G$. parviflora intercropping with $C$. hirsute were between two species monocultures respectively (Table 1). The soil sucrase activity of G. parviflora intercropping with $G$. aparine was higher than that of both G. parviflora (monoculture) and G. aparine (monoculture). When intercropped, the soil urease activities of G. parviflora intercropping with $C$. bursa-pastoris and $G$. parviflora intercropping with $G$. aparine were lower two species monocultures respectively, and $G$. parviflora intercropping with $C$. hirsute was between two species monocultures. The soil catalase activities of $G$. parviflora intercropping with $C$. bursa-pastoris and $G$. parviflora intercropping with 
C. hirsute was higher than that of two species monocultures respectively, and G. parviflora intercropping with $G$. aparine was between that of two species monocultures.

Table 1 Soil available nutrient concentration and soil enzyme activity

\begin{tabular}{|c|c|l|l|l|l|}
\hline Treatments & $\begin{array}{c}\text { Soil available } \\
\text { phosphorus } \\
(\mathrm{mg} / \mathrm{kg})\end{array}$ & $\begin{array}{c}\text { Soil available } \\
\text { potassium } \\
(\mathrm{mg} / \mathrm{kg})\end{array}$ & $\begin{array}{c}\text { Soil sucrase } \\
\text { activity } \\
(\mathrm{mg} / \mathrm{g})\end{array}$ & $\begin{array}{c}\text { Soil urease } \\
\text { activity } \\
(\mathrm{mg} / \mathrm{g})\end{array}$ & $\begin{array}{c}\text { Soil catalase } \\
\text { activity } \\
(\mathrm{ml} / \mathrm{g})\end{array}$ \\
\hline $\mathrm{GP}(\mathrm{Mo})$ & $4.25 \pm 0.20 \mathrm{ab}$ & $124.70 \pm 0.42 \mathrm{ab}$ & $0.297 \pm 0.014 \mathrm{e}$ & $0.471 \pm 0.021 \mathrm{ab}$ & $0.245 \pm 0.005 \mathrm{bc}$ \\
\hline $\mathrm{CB}(\mathrm{Mo})$ & $3.02 \pm 0.04 \mathrm{e}$ & $121.81 \pm 2.56 \mathrm{abc}$ & $0.865 \pm 0.010 \mathrm{a}$ & $0.476 \pm 0.013 \mathrm{a}$ & $0.259 \pm 0.013 \mathrm{~b}$ \\
\hline $\mathrm{CH}(\mathrm{Mo})$ & $3.35 \pm 0.11 \mathrm{~d}$ & $118.27 \pm 1.03 \mathrm{~cd}$ & $0.545 \pm 0.029 \mathrm{~d}$ & $0.345 \pm 0.006 \mathrm{~d}$ & $0.223 \pm 0.004 \mathrm{c}$ \\
\hline $\mathrm{GA}(\mathrm{Mo})$ & $4.09 \pm 0.09 \mathrm{bc}$ & $120.24 \pm 1.08 \mathrm{bc}$ & $0.555 \pm 0.024 \mathrm{~d}$ & $0.475 \pm 0.016 \mathrm{a}$ & $0.314 \pm 0.017 \mathrm{a}$ \\
\hline $\mathrm{GPIntCB}$ & $4.26 \pm 0.06 \mathrm{ab}$ & $115.44 \pm 0.79 \mathrm{~d}$ & $0.661 \pm 0.009 \mathrm{~b}$ & $0.443 \pm 0.010 \mathrm{~b}$ & $0.260 \pm 0.016 \mathrm{~b}$ \\
\hline GPIntCH & $3.94 \pm 0.07 \mathrm{c}$ & $121.99 \pm 2.81 \mathrm{abc}$ & $0.533 \pm 0.004 \mathrm{~d}$ & $0.408 \pm 0.001 \mathrm{c}$ & $0.253 \pm 0.013 \mathrm{bc}$ \\
\hline GPIntGA & $4.41 \pm 0.04 \mathrm{a}$ & $125.56 \pm 2.21 \mathrm{a}$ & $0.605 \pm 0.014 \mathrm{c}$ & $0.411 \pm 0.006 \mathrm{c}$ & $0.311 \pm 0.021 \mathrm{a}$ \\
\hline
\end{tabular}

Values are means of three replicate pots. Different lowercase letters indicate significant differences based on one-way analysis of variance in SPSS 13.0 followed by the least significant difference test $(p<0.05)$. GP(Mo) $=$ monoculture of $G$. parviflora, $\mathrm{CB}(\mathrm{Mo})=$ monoculture of $C$. bursa-pastoris, $\mathrm{CH}(\mathrm{Mo})=$ monoculture of $C$. hirsute, $\mathrm{GA}(\mathrm{Mo})=$ monoculture of G. aparine, $\mathrm{GPIntCB}=$ G. parviflora intercropping with $C$. bursa-pastoris, $\mathrm{GPIntCH}=$ G. parviflora intercropping with $C$. hirsute, $\mathrm{GPIntGA}=$ G. parviflora intercropping with G. aparine.

\section{Conclusions}

When intercropping with three accumulator species ( $C$. bursa-pastoris, $C$. hirsute and $G$. aparine), the total $\mathrm{P}$ and $\mathrm{K}$ contents in roots and shoots of $G$. parviflora were ranked as: $G$. parviflora (intercropping with G. aparine) $>$ G. parviflora (monoculture) $>$ G. parviflora (intercropping with $C$. hirsute) > G. parviflora (intercropping with $C$. bursa-pastoris). When intercropping with $G$. parviflora, the total $\mathrm{P}$ and $\mathrm{K}$ contents in roots and shoots of $C$. bursa-pastoris increased, but the total $\mathrm{P}$ and $\mathrm{K}$ contents in roots and shoots of $C$. hirsute and $G$. aparine decreased compared with monoculture respectively. Therefore, intercropping with $G$. aparine could used to increase nutrient uptake of G. parviflora in Cd-contaminated soil.

\section{References}

[1] C. Li, X. He, S. Zhu, H. Zhou, Y. Wang, Y. Li, J. Yang, J. Fan, J. Yang, G. Wang, Y. Long, J. Xu, Y. Tang, G. Zhao, J. Yang, L. Liu, Y. Sun, Y. Xie, H. Wang and Y. Zhu: PLoS ONE Vol. 4 (2009), p. e8049.

[2] S.N. Whiting, J.R. Leake, S.P. McGrath and A.J. Baker: Environmental Science \& Technology Vol. 35 (2001), p. 3237.

[3] B. Yang, W.S. Shu and Z.H. Ye: Chemosphere Vol. 52 (2003), p. 1593.

[4] L. Lin, Q. Jin, Y. Liu, B. Ning, M. Liao and L. Luo: Environ. Toxicol. Chem. Vol. 33 (2014), p. 2422.

[5] Y. Liu, L. Lin, Q. Jin and X. Zhu: Environmental Progress \& Sustainable Energy Vol. 34 (2015), p. 663.

[6] L. Lin, J. Shi, Q. Liu, M. Liao and L. Mei: Environmental Monitoring and Assessment Vol. 186 (2014), p. 4051.

[7] S.D. Bao: Agrochemical Soil Analysis ( $3^{\text {rd }}$ edition, China Agriculture Press, Beijing 2000).

[8] L.K. Zhou: Soil Enzymology (Science Press, Beijing 1987). 